\title{
A digital photographic technique for assessing forage utilization
}

\author{
P. W. HYDER, E. L. FREDRICKSON*, M. D. REMMENGA, R. E. ESTELL, R. D. PIEPER, AND D.M. ANDERSON
}

Authors are Senior Research Assistant and Research Scientist, USDA, Agricultural Research Service, Jornada Experimental Range, Las Cruces, N.M. 88003, associate professor, University Statistics Center, New Mexico State University, Research Animal Scientist, USDA, Agricultural Research Service, Jornada Experimental Range, Las Cruces, N.M. 88003, Professor Emeritus, Department of Animal and Range Sciences, New Mexico State University, and Research Animal Scientist, USDA, Agricultural Research Service, Jornada Experimental Range. *Corresponding author.

\begin{abstract}
Changes in forage utilization have been difficult to measure non-destructively without some level of subjectivity. This subjectivity, combined with a lack of reproducibility of visual estimates, has made forage utilization measurement techniques a topic of considerable discussion. The objective of this study was to develop and test the accuracy and repeatability of an objective, computer-based technique for measuring changes in plant biomass. Digital photographs of target plants acquired before and after partial defoliation were analyzed using readily available image analysis software. Resulting data were used to develop a simple linear random coefficient model (RC) for estimation of plant biomass removed based on the area of the plant in the photo. Sample collection took approximately 20 minutes/plant for alfalfa (Medicago sativa L.). Analysis of images took another 60 to 90 minutes. Regression analysis gave an $R^{2}$ of 0.969 for predicted vs. observed plant weights. Testing this model using 10 alfalfa plants yielded weight estimates of defoliated plants accurate to within $+/-8.5 \%$. The advantage of the RC model is its ability to use easily obtained coefficients from simple linear regression models developed from each plant in a way that accounts for the lack of independence between samples within an individual plant. The technique described here offers an objective and accurate method for measuring changes in plant biomass with possible applications in ecology, botany, and range science. In particular, application of this technique for estimating forage utilization may improve accuracy of estimates and, thereby, improve range management practices.
\end{abstract}

Key Words: image analysis, alfalfa, Medicago sativa, random coefficient model.

Measurement of current-year's forage production that is either consumed or destroyed by grazing animals (Society for Range Management 1974) is critical for successful rangeland management. Despite the importance of accurately measuring range utilization, methods currently available have various constraints that limit their usefulness (Holechek et al. 1989). Techniques that

The authors would like to thank 2 anonymous reviewers for their constructive comments. Field assistance from David Hu and Andrine Morrison is greatly appreciated.

Trade names used in this publication are solely for the purpose of providing specific information. Mention of a trade name does not constitute a guarantee, endorsement, or warranty of the product by the U. S. Department of Agriculture or New Mexico State University.

Manuscript accepted 25 May 02

\section{Resumen}

Los cambios en la utilización de forraje han sido difíciles de medir en forma no destructiva sin un grado de subjetividad. Esta subjetividad, combinada con la carencia reproducción de las estimaciones visuales, ha hecho que las técnicas de medición de utilización de forraje sea un tópico de considerable discusión. El objetivo de este estudio fue desarrollar y probar la certeza y repetibilidad de una técnica computacional objetiva para medir la biomasa vegetal. Fotografías digitales de plantas de interés tomadas antes y después de ser sujetas a una defoliación parcial fueron analizadas utilizando programas de computación ya disponibles para el análisis de imágenes. Los datos resultantes fueron utilizados para desarrollar un modelo lineal simple de coeficiente aleatorio (RC) para estimar la biomasa vegetal removida basándose en el área de la planta en la fotografía. La colección de la muestra tomó aproximadamente 20 minutos/planta de "Alfalfa" (Medicago sativa L.), el análisis de las imágenes tomo otros 60 a 90 minutos. EI análisis de regresión produjo una $R^{2}$ de 0.969 para los pesos de planta predichos contra los observados. La prueba de este modelo usando 10 plantas de "Alfalfa" produjo estimaciones de peso de las plantas defoliadas con una certeza dentro de $+/-8.5 \%$. La ventaja del modelo RC es su capacidad para usar coeficientes fácilmente obtenidos a partir de modelos de regresión lineal desarrollados de cada planta en una manera que toma en cuenta la falta de independencia entre muestras dentro de una planta individual. La técnica descrita aquí ofrece un método objetivo y certero para medir cambios en la biomasa de las plantas con posibles aplicaciones en ecología, botánica y manejo de pastizales. En particular, la aplicación de esta técnica para estimar la utilización de forraje puede mejorar la certeza de las estimaciones, por lo tanto, mejorar las prácticas de manejo de pastizales.

allow greater accuracy and can detect small differences in animal use are extremely tedious and labor intensive. These latter problems severely limit quantitative research because large sample sizes are required to obtain accurate forage use estimates (Estell et al. 1998). The objective of the work described in this paper was to develop a rapid, accurate, and repeatable quantitative technique for objective assessment of forage utilization. We also desired a technique that was readily available to most researchers at reasonable costs. To accomplish this task, we focused on recent technological advancements in digital photography and image analysis. The photographic aspect of this method adds a level of flexibility and reliability not found in other methods. 
Photographs provide a permanent record that allows an objective estimate of the area, and through modeling, the mass of a plant to be calculated.

\section{Materials and Methods}

\section{Field Technique}

The field component of this study was conducted at the USDA, Agricultural Research Service, Sheep Research Facility located at the La Tuna Federal Correctional Institute in Anthony, Tex. Alfalfa (Medicago sativa L.) was used because of its importance as a forage plant. Fifty alfalfa plants were randomly selected from a $10 \times 2$-m plot. Each plant was transplanted to a 5-gallon bucket. Transplanting each plant allowed us to deal with developing the technique on a plant-by-plant basis with no interference from neighboring plants or other objects. To separate the plant from the background, a sheet of white, dry-erase board was placed behind, but not touching, the plant (Fig. 1A). Plant identification, date, sample number, and photo angle were recorded on the dry-erase board. A ruler attached to a wire was placed to the side of the plant on a plane bisecting the midpoint of the plant. Each ruler was held in place by inserting the attached wire into the soil. A second ruler was placed perpendicular to the first, also on a plane bisecting the plant's midpoint. These rulers served to calibrate the image and to establish 0 and $90^{\circ}$ reference angles. To improve calibration accuracy, the rulers were trimmed to a total length of $10 \mathrm{~cm}$, eliminating the need to see the marks on the ruler.

A digital camera (Kodak® DC260) was used to photograph the plants. Two photographs were taken at each sampling stage (sample 0-k) with the first 2 taken prior to defoliation (sample 0). The first photograph of each pair was taken at the midpoint of the plant height and width from a direction minimizing shadows. The second was taken at $90^{\circ}$, on a horizontal plane, from the first. The white backdrop was also rotated at each step.

Plants were hand-defoliated in 5 steps. Approximately $20 \%$ of the total plant weight was removed and collected as a sample during each step. As each sample was collected, the sample number was recorded on the backdrop and the plant rephotographed. Succeeding photos were taken from as close to the same position as possible. Samples collected at each step were bagged and labeled separately. During the last defoliation step, all remaining above ground tissue was removed. Each sample was dried at $60^{\circ} \mathrm{C}$ for 24 hours prior to being weighed to the nearest $0.5 \mathrm{~g}$. The weight of each defoliation was recorded and then summed to determine total weight of the plant.

\section{Image Analysis}

Jandel's SigmaScan Pro® 3.0 was used to analyze the digital images. Any image analysis software could be used provided it has something approximating the following capabilities: image cropping, calibration of scale, color/black and white/contrast transforms, intensity selection procedures, and some form of data reporting program. These are used to prepare the image of the plant for areal measurement. Image cropping helps isolate the target image from incidental objects. This will become important as the technique evolves for use in the field. Once the image is adequately prepared, the program counts pixels of various values that correspond to the image. These pixels are then transformed to area based on the measurement of a known distance on the image, in this case the $10-\mathrm{cm}$ ruler, to the number of pixels contained in the length of the image of the ruler. Color/black and white/contrast transforms and intensity selection procedures enhance isolation and measurement of the target image (Fig. 1B, C, and D). In our method, the color image was transformed to black and white (grayscale) due to the program we used being better able to delineate the image in black and white. Once the measurements are made, such that a calculation of area for each image is available, the data can be copied into a spreadsheet for further analysis.

Sample weights and photographic areas were converted to percent weight remaining and percent area remaining, respectively. We used a mean calculated from the percent remaining areas for angles $0^{\circ}$ and $90^{\circ}$ to address the 3 dimensional aspect in a 2 dimensional form. Forty plants were used to develop a statistical model and 10 plants to test the model. To test for repeatability of the image analysis, we calculated the area for 1 plant image 10 times. To test sampling precision, we calculated the mean deviation from the desired $20 \%$ defoliation sample size and standard deviation of this mean for the samples taken from the 40 plants used to build the model.

\section{Model Building}

A statistical model was constructed to provide estimates of individual plant utilization, specifically for this particular
Table 1. Example data used to demonstrate statistical methods.

\begin{tabular}{cccc}
\hline \hline Plant & Sample & $\begin{array}{c}\text { Area remaining } \\
\text { in photograph }\end{array}$ & $\begin{array}{c}\text { Weight of } \\
\text { remaining } \\
\text { plant }\end{array}$ \\
\hline & 1 & $(\%)$ & $(\%)$ \\
1 & 2 & 87 & 93 \\
1 & 3 & 48 & 77 \\
1 & 4 & 30 & 59 \\
1 & 5 & 13 & 24 \\
1 & 5 & 91 & 93 \\
\hline 2 & 1 & 71 & 77 \\
2 & 2 & 52 & 61 \\
2 & 3 & 27 & 38 \\
2 & 4 & 14 & 25 \\
2 & 5 & 89 & 94 \\
\hline 3 & 1 & 72 & 78 \\
3 & 2 & 50 & 60 \\
3 & 3 & 30 & 41 \\
3 & 4 & 19 & 28 \\
3 & 5 & 86 & 92 \\
\hline 4 & 1 & 67 & 76 \\
4 & 2 & 47 & 58 \\
4 & 3 & 27 & 39 \\
4 & 4 & 13 & 24 \\
4 & 5 & & \\
\hline
\end{tabular}

variety of alfalfa (Malone) at this particular stage of growth. The random coefficient (RC) model was used and can be written as $\left[y_{i j}=\beta_{0}+s_{i}+\left(\beta_{1}+d_{i}\right) x_{i j}+e_{i j}\right.$, $\mathrm{i}=1, \ldots, \mathrm{n}$ and $\mathrm{j}=1, \ldots, k]$ where $\mathrm{y}_{\mathrm{ij}}$ is the percentage of the $i^{\text {th }}$ plant remaining after the $\mathrm{j}^{\text {th }}$ sample is removed, $\mathrm{x}_{\mathrm{ij}}$ is the remaining area covered in the photograph of the ith plant after the jth sample is removed, $\beta_{0}$ is the $y$-intercept, $\beta_{1}$ is the slope, and $s_{i}, d_{i}$, and $e_{i j}$ are random effects in the model associated with the random deviation of the $i^{\text {th }}$ plant's intercept from the intercept $\beta_{0}$, the random deviation of the $i^{\text {th }}$ plant's slope from the slope $\beta_{1}$, and random error, respectively (Graybill 1976).

The first step in building the RC model is to estimate a simple linear regression (SLR) equation for each plant. Each SLR equation describes the straight-line relationship between the percentage of remaining plant $(y)$ and the percentage of remaining area covered in the photograph (x) for a single plant. In general notation, let $b_{0 \mathrm{i}}$ and $b_{1 \mathrm{i}}$ denote the estimated $\mathrm{y}$ intercept and slope for the $\mathrm{i}^{\text {th }}$ plant $(\mathrm{i}=$ $1, \ldots, n)$. Computations were performed using fifteen significant digits and rounded to one for illustration purposes. The estimated SLR equation for the $\mathrm{i}^{\text {th }}$ plant is $\mathrm{Y}_{\mathrm{ij}}$ $=b_{0 \mathrm{i}}+b_{1 \mathrm{i}} \mathrm{x}_{\mathrm{i}}$.

A small subset of the data set $(n=4, k=$ 5 ) is given in Table 1 to use in illustrations of the statistical computations. The estimated SLR equations and associated sums of squared residuals for each of the 4 plants in Table 1 are reported in Table 2. 
Table 2. Estimated Simple Linear Regression (SLR) equations and Sum of Squared Residuals relating the percentage of remaining plant $(y)$ to the percentage of remaining area covered in the photograph $(x)$ for each plant in Table 1.

\begin{tabular}{ccc}
\hline \hline Plant & SLR Equation & $\begin{array}{c}\text { Sum of Squared } \\
\text { Residuals }\end{array}$ \\
\hline 1 & $\mathrm{y}=13.25+0.9337 \mathrm{x}$ & 6.9594 \\
2 & $\mathrm{y}=13.77+0.8829 \mathrm{x}$ & 4.7088 \\
3 & $\mathrm{y}=12.15+0.9241 \mathrm{x}$ & 7.5185 \\
4 & $\mathrm{y}=13.24+0.9283 \mathrm{x}$ & 4.9426 \\
\hline
\end{tabular}

The y-intercept and slope of the RC equation are estimated by computing the sample averages of the estimated individual plant y-intercepts and slopes, respectively. The estimators for the y-intercept and slope can be written as

and

$$
\hat{\beta}_{0}=\frac{1}{n} \sum_{i=1}^{n} b_{0 i}
$$

$$
\hat{\beta}_{1}=\frac{1}{n} \sum_{i=1}^{n} b_{1 i}
$$

respectively. For our example,

$$
\hat{\beta}_{0}=\frac{1}{4} \sum_{i=1}^{4} b_{0 i}=(13.2+13.8+12.1+13.2) / 4=13.1
$$

and $\hat{\beta}_{1}=\frac{1}{4} \sum_{i=1}^{4} b_{1 i}=(0.93+0.88+0.92+0.93) / 4=0.92$

Thus, the estimated equation for the RC model is $\hat{y}_{i j}=\hat{\beta}_{0}+\hat{\beta}_{1} x=13.1+0.92 x$ for this example.

The estimated mean of $y$ at a given value of $\mathrm{x}($ say $\mathrm{x} *$ ) is

$$
\left(\hat{y} \mid x=x^{*}\right)=\hat{\beta}_{0}+\hat{\beta}_{1} x^{*}
$$

For the example, an estimate of the percentage of a plant remaining that was observed to have, say, $80 \%$ of the area remaining in a photograph of the plant after it was browsed by an animal, is y given $x=80$ or $(\hat{y} \mid x=80)=\hat{\beta} 0+\hat{\beta} 1(80)$ $=13.1+0.92 \mathrm{x}=86.5$.

\section{Results and Discussion}

Theoretically, the limit for detection of biomass removal should correspond to the area of the photo covered by a pixel given that the tissue removed is on a plane visible to the camera, i.e., not hidden by intervening tissue. This plane of visibility is probably the most important source of variation in the individual plant models.
Photographing plants from perpendicular directions and taking the mean area of the 2 images helped to reduce variation incorporated into the model by the 3-dimensional shape being reduced to 2 dimensions during analysis. Estimates of the remaining percentages of plant weights were accurate to $+/-21 \%$ using the $0^{\circ}$ angle photographs and to $+/-17 \%$ using the $90^{\circ}$ angle photographs, but were accurate to $+/-8.5 \%$ using the mean of the $0^{\circ}$ and $90^{\circ}$ angle photographs. The mean area for the repeated images was $676 \mathrm{~cm}^{2}$ (SD $=21.61, \mathrm{CV}=3.19, \mathrm{n}=10)$. The basic premise, that a pair of photographs taken at perpendicular angles can adequately model the 3-dimensional plant, seems to hold up well.

Problems encountered were the inability to distinguish plant tissue from background clutter, poor image quality, and increasing area with decreasing biomass. The backdrop solved the background clutter problem. Using a digital camera and image manipulating software allows the operator to manipulate image factors and does much to solve image quality problems. The area-biomass problem is typically the result of allowing the background screen to contact the plant or photographing the plants under windy conditions thereby changing the apparent area between photographs. These 2 factors are the main contributors to the plane of visibility problem mentioned above. To ensure the repeat positioning of the camera for sequential shots, one could use 2 tripods placed at right angles to the plant and simply move the camera between the tripods. The use of quick release heads on the tripods would facilitate this approach. With SigmaScan Proß 3.0, the set threshold routine is a potential source of subjectivity. Carefully setting the threshold values in the first image so that plant tissue is maximized and extraneous material is minimized and then holding this value constant throughout the series of images will minimize the subjectivity inherent in this step. Figure 1D shows an example of a threshold setting where plant tissue is highlighted, but shadows and grass stems are not

There are additional considerations if film is used. In a previous trial, we used Kodachrome, 64 slide film. Upon return of the processed slides, they were digitized with a Nikon Coolscan ${ }^{\circledR}$ slide digitizer. This gave us good control over the image quality with respect to setting up the image for further analysis. Prints could possibly be used with a flatbed scanner, but the superior resolution, for a given film speed, of slides vs. prints may argue against the use of print film. This difference in resolution is due to the inherent loss of information that occurs when an image is transferred to a different medium, i.e., film negative to paper. It is possible that this loss of resolution would be too small to have an effect on this technique. A fast film (ISO of 200 or more) used with flash would enable working during periods of light to moderate winds. The use of a flash should help reduce problems created by shadows. Depth of field should be maximized so that the entire image of the plant is as sharp as possible.

Time investments in this technique are somewhat longer than with previous methods listed in Table 3 , but the improved

Table 3. Comparison of methods for estimating utilization.

\begin{tabular}{lcc}
\hline \hline Method & Time & Accuracy \\
\hline & (days) $^{\mathrm{a}}$ & $(\%)$ \\
Digital Photographic & 4 & \pm 8.5 \\
Ocular by Plot $^{\mathrm{b}}$ & 2 & +19 \\
Ocular by Plant $^{\mathrm{b}}$ & & +2 \\
Leaf Length $^{\mathrm{b}}$ & & +16 \\
Plant Count $^{\mathrm{b}}$ & & +26 \\
Height/Weight Ratio $^{\mathrm{c}}$ & & $+10-25$ \\
\hline
\end{tabular}

${ }^{\mathrm{a}}$ Time includes model building and training.

${ }^{\mathrm{b}}$ Pechanec and Pickford (1937) (these values are means). Clark (1945)

results offset the increased time invested. Collecting samples and photographing alfalfa plants took an average of $20 \mathrm{~min}$ utes/plant. A large part of the post-sampling time spent depends on the camera used. Digital cameras provide usable images immediately. Turn-around time for development of film is dependent on whether the film is sent to a lab or developed in house. Once slides, or digitized images, are available, the process takes 3 to 5 minutes per image to calculate the variables of interest. This data is then transcribed to spreadsheet form and appropriate statistical analyses completed. Training of inexperienced individuals could probably be done in 2 sessions of roughly 4 hours each, an hour each for photography, digitizing, image analysis, and data collection plus some time to practice the technique. Once simple linear regression equations are computed for each plant, construction of the random coefficient model is relatively easy.

Statistical analysis of this data set using simple linear regression across all plants would seem to be an intuitive approach. An important assumption associated with simple linear regression (SLR) is that the 

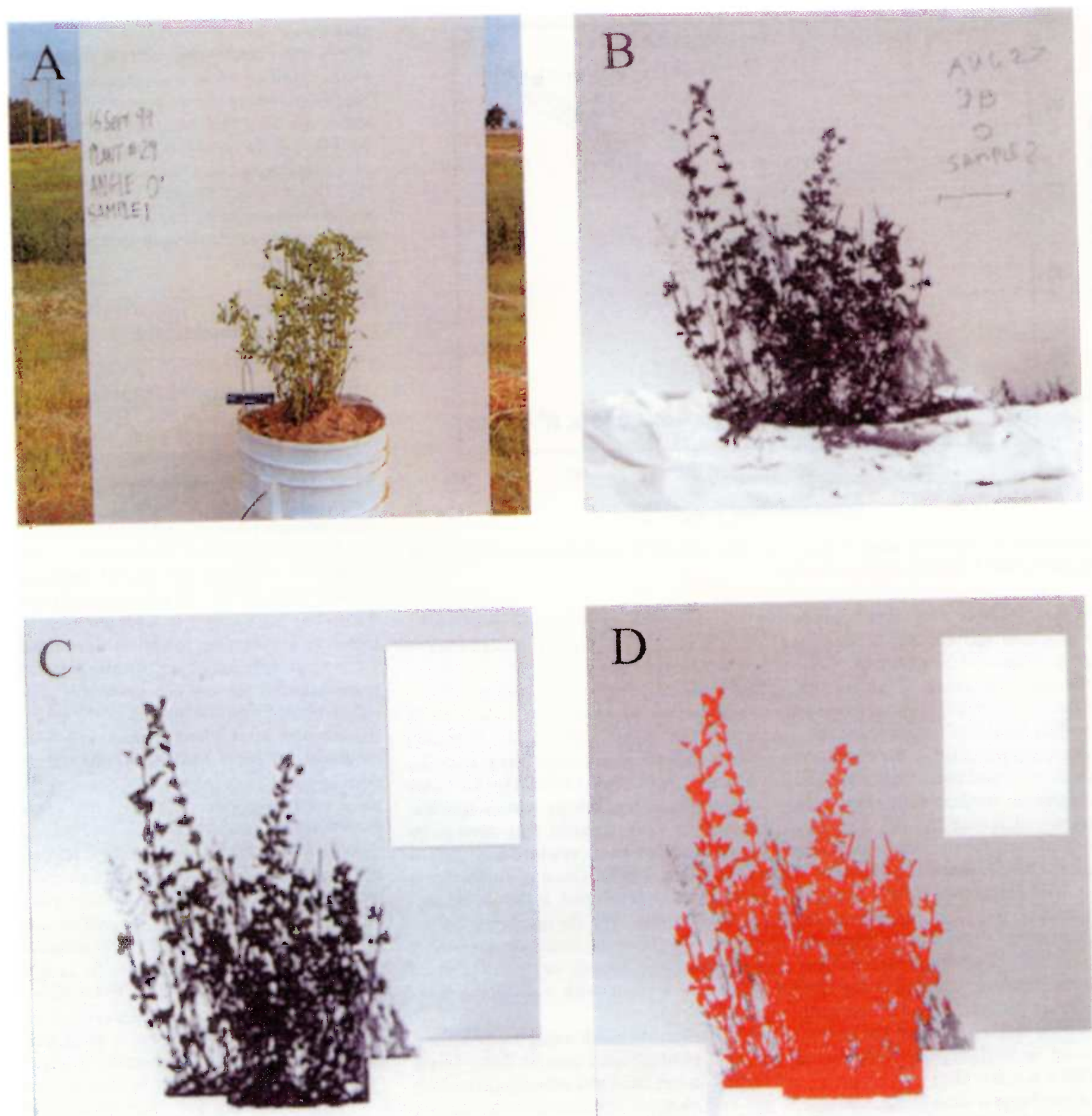

Fig. 1. A. Apparatus for separating plant from background. B. Image set in black and white. C. Cleaned image. D. Image ready for measuring.

random variable $(y)$ at each value of $x$ is independent of the random variable $y$ at any other value of $\mathrm{x}$. In the present work, sequential samples were taken from each plant resulting in measures of biomass $(y)$ at various values of area (x) that are not independent of each other. The RC modet addresses the problem of a lack of independence by using the line produced for each plant by simple linear regression as the attribute of interest. From a statistical perspective, this approach is preferred because the estimates are more precise and because the sources of variability can be partitioned and examined to improve future models.

The RC model fit to the data from 40 of the alfalfa plants resulted in the equation
$\left[Y_{i j}=9.06+0.976 x\right]$. Figure 2 shows the estimated and observed percentages of plant remaining for sample points from 10 plants not used in constructing the model. There is an increased sensitivity at lower levels of defoliation. The greater sensitivity is advantageous due to desired utilization levels, which usually requires leaving more than $50 \%$ of the plant. 


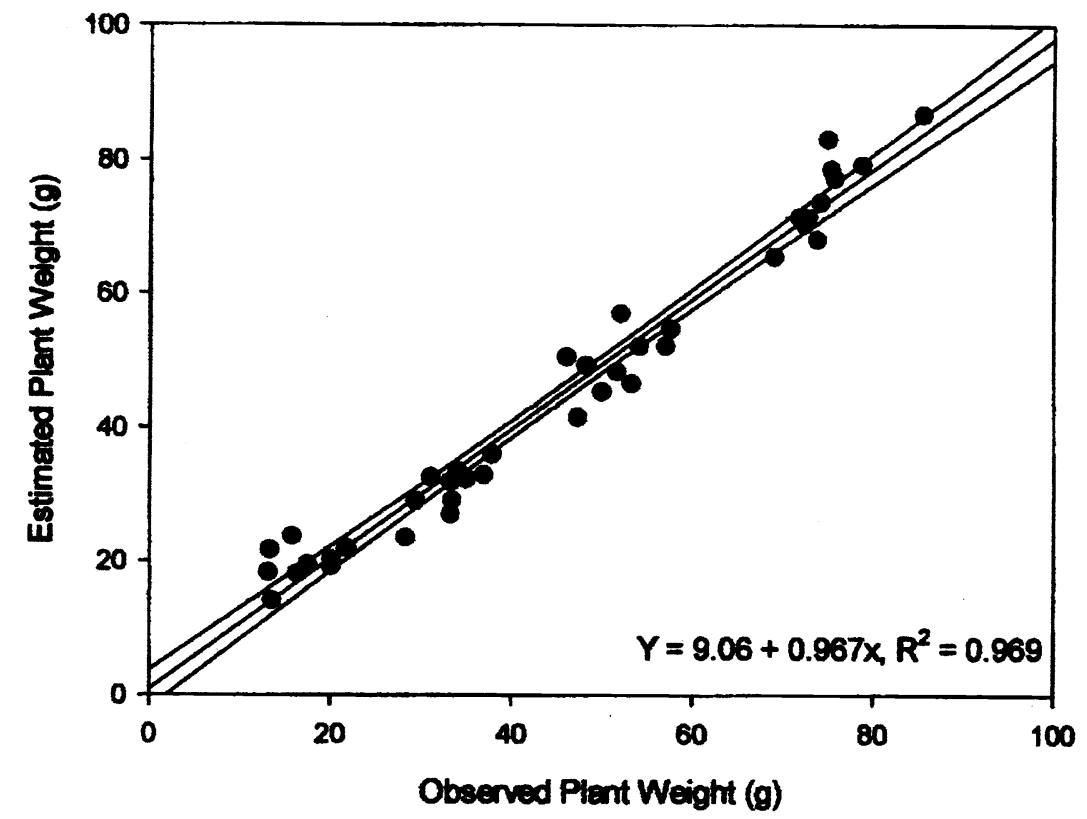

Fig. 2. Estimated vs. observed plant weight remaining with $95 \%$ confidence intervals for 10 alfalfa plants with 4 samples from each plant.

The optimal sample allocation between number of plants and number of samples per plant is dependent on plant morphology. However, because of statistical assumptions of normality, we recommend no fewer than 30 plants. The optimal number of measures per plant is dependent on the researcher's experience with the sample/photographic methodology. However, for purposes of fitting the RC model, a minimum of 4 measurements per plant including the whole plant measurement is required. The researcher must conscientiously attempt to select samples at the same $\mathrm{x}$-values for each plant to meet statistical assumptions of the model. For our samples, the mean deviation from the ideal $20 \%$ intervals between areas of consecutive samples within a plant for the 40 plants used in building the model was $12.5 \%(\mathrm{SD}=6.2, \mathrm{n}=160)$.

One of the biggest drawbacks with current methods of forage and browse utilization is the level of subjectivity required. Ocular estimates rely on the experience of the observer and may be subject to individual bias, particularly if the observer is not well trained or fails to periodically check his observations against a standard (Bement and Klipple 1959). Height/weight methods generally perform well, but are dependent on plants used to develop the model being similar in morphology to the plants being estimated (Clark 1945). The technique described in this paper incorporates aspects of several methods. It is similar to ocular-estimate-by-plant and height/weight methods in that individual plants are used as the basic units and a weight/area relationship is developed (Lommasson and Jenson 1938, Cook and Stubbendieck 1986). The digital-photographic method minimizes subjectivity through the use of photographs. Repeated measurements of an image gave a coefficient of variation of $3.19 \%$. Due to variation in plant morphology across species, seasons, or sites, a model may need to be developed for each application (Caird 1945, Clark 1945). Once a model for a given plant is developed, it should be useful indefinitely. We do not know at the present time what the limits on usefulness are for a given model, say alfalfa, when applied to a plant with a different morphology.

Collection of plant samples and their related photographs can be done fairly rapidly in the field and subsequent modeling and analysis completed in the laboratory. Additionally, photographs from sites to be analyzed for forage utilization can be taken and analyzed at a time convenient to the individual doing the assessment. A series of forage conditions could be photographed at intervals throughout the season and an analysis of season-long changes could be carried out. This technique will be difficult to use on large harvesting the entire plant for modeling. Estimates of weight/unit area may allow the use of this method for large shrubs or trees although indirect methods are probably of more value (Bonham 1989). Also, this method has not yet been tested on shrubs or trees due to the limitations of grasses or woody plants. Any situation where individual plants can be delineated in the field of view will probably work. Situations where plants are in close proximity, such as turf, may be problematic. As software of this type develops, the use of variation in color will likely improve the ability to differentiate specific targets and thereby improve the utility of digitalphotographic methods such as the one presented here.

\section{Conclusions}

The digital-photographic method described herein accurately estimated the weight of individual alfalfa plants at sequential defoliation episodes to within \pm $8.5 \%$. The weight values were calculated from paired perpendicular photographs taken of each plant at each level $(0,20,40$, 60,80 , and $100 \%$ ) of defoliation. Time needed to complete the model building varied from 22 to 32 hours total time depending on familiarity with techniques. Once an appropriate model is developed for a plant species, objective estimates of plant material present can be readily calculated based on photographs of the plant. Before and after photographs will give estimates of plant biomass removed, or remaining, if photographs are obtained in short enough temporal intervals that plant growth or leaf abscission does not become a confounding factor. Within this context, plant phenology should not affect estimates. The use of a digital-photographic method for estimating plant biomass lost to herbivores has applications in agriculture, ecology, and other fields. As image analysis technology improves, the applicability and accuracy of techniques such as this will improve. One aspect in particular need of improvement is the ability to separate target plants or groups of plants from background objects. For most shrubs and forbs in arid and semiarid environments that have a random or regular distribution, the problem associated with plant separation should be minimal. In all cases, the use of blocking objects, such as the backing board used here, will be needed to separate the plant from its background. The use of readily available computer technology and photographic equipment will decrease the subjectivity and increase the accuracy of field measurements of plant geometry and associated losses due to herbivory and/or other factors. 


\section{Literature Cited}

Bement, R.E. and G.E. Klipple. 1959. A pasture comparison method of estimating utilization of range herbage on the central Great Plains. J. Range Manage. 12:296-298.

Bonham, C.D. 1989. Measurements for terrestrial vegetation. John Wiley \& Sons, New York, N.Y.

Caird, R.W. 1945. Influence of site and grazing intensity on yields of grass forage in the Texas Panhandle. J. Forest. 43:45-49.

Clark, I. 1945. Variability in height of forage grasses in central Utah. J. Forest. 43:273-283
Cook, C.W. and J. Stubbendieck. 1986. Range research: basic problems and techniques. Soc. Range Manage., Denver, Colo.

Estell, R.E., E.L. Fredrickson, D.M. Anderson, K.M. Havstad, and M.D. Remmenga. 1998. Relationship of tarbush leaf surface terpene profile with livestock herbivory. J. Chem. Ecol. 24:1-12.

Graybill, Franklin A. 1976. Theory and application of the linear model. Duxbury Press, North Scituate, Mass.

Holechek, J.L., R.D. Pieper, and C.H. Herbel. 1989. Range management: principles and practice. Prentice Hall, Engelwood Cliffs, N.J.
Lommasson, T. and C. Jensen. 1938. Grass volume tables for determining range utilization. Sci. 87:444.

Pechanec, J.F. and G.D. Pickford. 1937. A comparison of some methods used in determining percentage utilization of range grasses. J. Agr. Res. 54:753-765.

Society for Range Management. 1974. A glossary of terms used in range management, $2^{\text {nd }}$ Edition. Soc. Range Manage., Denver, Colo. 